(2) Open Access Full Text Article

ORIGINAL RESEARCH

\title{
Association between glycemic status and thyroid dysfunction in patients with type 2 diabetes mellitus
}

This article was published in the following Dove Press journal:

Diabetes, Metabolic Syndrome and Obesity: Targets and Therapy

\author{
SU Ogbonna' \\ IU Ezeani' \\ $\mathrm{Cl}$ Okafor $^{2}$ \\ S Chinenye ${ }^{3}$ \\ 'Department of Internal Medicine, \\ Federal Medical Center, Umuahia, Abia \\ State, Nigeria; ${ }^{2}$ Department of Internal \\ Medicine, University of Nigeria Teaching \\ Hospital, Enugu, Enugu State, Nigeria; \\ ${ }^{3}$ Department of Internal Medicine, \\ University of Port Harcourt Teaching \\ Hospital, Port Harcourt, Rivers State, \\ Nigeria
}

Background: Thyroid dysfunction has been widely reported to be more common in patients with type 2 diabetes mellitus (T2DM) in various parts of the world; however, there is paucity of data on this in our environment.

Objective: The aim of this study was to determine the possible relationship between glycemic status and thyroid dysfunction.

Methodology: A total of 354 T2DM patients and 118 non-diabetic persons (controls) were recruited for the study. A pretested questionnaire was filled for each subject after due explanations. Their blood samples were tested for HbA1c, fT3, fT4, and TSH. Information retrieved from patient's medical records included age at diagnosis of diabetes (DM) and duration of DM. Testing statistics done included Student's $t$-test, chi square test, and regression analysis. $P$-value of less than 0.05 was taken to be statistically significant.

Results: The results show that $43.5 \%$ and $37.3 \%$ of T2DM and control subjects, respectively, were males. Mean HbA1c was significantly higher in T2DM patients than in the controls $(7.8 \pm 2.0 \%$ vs $5.8 \pm 1.2 \%, p=0.001)$, while mean fT3 was significantly lower in T2DM patients than in the controls $(2.3 \pm 1.5 \mathrm{pg} / \mathrm{mL}$ vs $2.7 \pm 2.2 \mathrm{pg} / \mathrm{mL}, p=0.03)$. Mean HbA1c was significantly higher in T2DM patients with thyroid dysfunction compared to their euthyroid counterparts $(8.1 \pm 1.9 \%$ vs $5.1 \pm 1.2 \%, p=0.001)$. HbA1c had a positive linear relationship with the presence of thyroid dysfunction (regression coefficient $=1.89, p=0.001$ ).

Conclusion: There was a positive linear relationship between $\mathrm{HbAlc}$ and the presence of thyroid dysfunction in the T2DM patients in this study. There was an inverse relationship between HbA1c and serum fT3.

Keywords: thyroid dysfunction, type 2 diabetes mellitus, hypothyroidism, South East Nigeria, relationship, glycemic status

\section{Introduction}

Thyroid dysfunction is a spectrum of disorders of the thyroid gland which manifests either as hyperthyroidism or hypothyroidism and is reflected in the circulating levels of thyroid-stimulating hormone (TSH). ${ }^{8}$ Thyroid dysfunction may present in one of the following ways - thyroid enlargement (diffuse or nodular); symptoms of thyroid hormone deficiency (hypothyroidism); symptoms of thyroid hormone excess (thyrotoxicosis); some have no symptoms (ie the subclinical state). ${ }^{8}$

Thyroid hormones affect glucose metabolism through several mechanisms. In hyperthyroidism, the half-life of insulin is reduced, most likely due to an increased rate of degradation and enhanced release of biologically inactive insulin precursors. ${ }^{1,2}$
Department of Internal Medicine, Federal Medical Center, PMB 700I, Umuahia, Abia State, Nigeria

Tel +234806069 2131

Email ignatiusezs@yahoo.com 
Untreated hyperthyroidism has been reported to be associated with a reduced c-peptide to pro-insulin ratio, suggesting an underlying defect in pro-insulin processing. ${ }^{3}$ Increase in gut absorption of glucose, mediated by excess thyroid hormones, ${ }^{4,5}$ is yet another mechanism through which thyroid hormones affect glucose metabolism. Thyroid hormones produce an increased hepatocyte plasma membrane concentrations of GLUT-2 (glucose transporter in the liver), which leads to an increased hepatic glucose output and abnormal glucose metabolism. ${ }^{6,7}$ The influence of diabetes mellitus (DM) on thyroid function has been established at the following sites: a) at the level of hypothalamic control of thyroidstimulating hormone (TSH) release, b) at the conversion of T4 to T3 in the peripheral tissues ${ }^{8}$ and c) the effect of hyperinsulinemia on the thyroid gland. ${ }^{8,9}$

The association between DM and thyroid dysfunction was first reported in 1979. ${ }^{10,11}$ The prevalence of thyroid dysfunction in diabetes varies from $2.2 \%$ to $46.5 \%{ }^{8-18}$

Previous studies have shown that thyroid dysfunction is more common in persons with type 2 DM (T2DM) than in the general population. ${ }^{9,15,18}$ Subclinical hypothyroidism has been reported in most of the studies to be the most common thyroid dysfunction in T2DM patients. ${ }^{8,9,18}$ Thyroid dysfunction has been widely reported among persons with diabetes in other parts of the world. In Nigeria, few studies ${ }^{13,16,18}$ have been reported on the prevalence of thyroid dysfunction among persons with DM, but only one of them ${ }^{18}$ focused on T2DM and few studies have compared the levels of thyroid hormone with glycemic status in diabetic patients. The aim of this study was to determine the possible relationship between glycemic status and thyroid dysfunction. This study focused on T2DM patients and will therefore add to the Nigerian literature, more so, as it is the first in South- East Nigeria.

\section{Methodology}

The study was conducted at the University of Nigeria Teaching Hospital (UNTH), Enugu, a Federal government tertiary hospital located in Ituku-Ozalla, Enugu state in South-East geographical region of Nigeria. This is a descriptive cross-sectional study involving patients with T2DM attending the Diabetes Clinic, or receiving treatment in the Medical Wards of the UNTH Enugu. Subjects were recruited using systematic sampling. A total number of 354 subjects were recruited from consenting persons with T2DM in the Diabetes Clinic and Medical Wards of the UNTH Enugu. For every three study subjects selected, one consenting person who did not have DM was recruited from the out-patients clinics and other parts of the hospital to serve as the control. Screening for DM was done in controls using the random blood glucose (RBG). Those with RBG of less than $11.1 \mathrm{mmol} / \mathrm{L}$, had no classic symptoms of hyperglycemia and were not on any hypoglycemic medications were accepted as controls. ${ }^{19}$ The inclusion criteria included:

(a) All patients with T2DM irrespective of blood pressure status,

(b) Patients who have attained 40 years of age at the time of diagnosis of $\mathrm{DM}^{20}$

(c) Those who had no thyroid surgery nor trauma to the neck.

(d) Subjects with no history of previous exposure to radiation to the neck.

(e) Those consenting to the study.

Exclusion criteria included:

1. Patients less than 40 years of age at diagnosis of DM

2. Those with history of neck trauma or surgery

3. Pregnant women

4. Subjects with history of previous exposure of radiation in the neck

5. Non-consenting patients

6. Patients on drugs like amiodarone, lithium, interferon alpha, iodides, beta blockers, carbimazole, propylthiouracil, potassium iodide, lugol's iodine

7. Patients with thyroid disorders.

8. Patients previously diagnosed to have type $1 \mathrm{DM}$ (T1DM).

\section{Ethical clearance}

Ethical approval was obtained from the University of Nigeria Health Research Ethics Committee of the UNTH Enugu before commencing the study. Written informed consent was obtained from all subjects participating in the study. This study was conducted in accordance with the declaration of Helsinki.

All subjects were interviewed, using a pre-tested structured questionnaire. Demographic information and other relevant data were obtained. The neck was examined for presence of enlarged thyroid gland. Routine examinations for the complications of DM were also carried out. Fundoscopy was done with the assistance of an Ophthalmologist. The participants were examined for 
peripheral neuropathy using tuning fork (vibration sense) and tendon hammer (deep tendon reflex). Anthropometric measurements such as weight and height were taken.

Anthropometric measurements such as weight and height were taken using a standard scale and stadiometer from Lincoln Mark Medical England; waist and hip circumference were measured using a measuring tape. Body Mass Index (BMI) was calculated from their weights measured in kilograms $(\mathrm{kg})$ and heights in meters $(\mathrm{m})$ using the standard formula., ${ }^{9,21}$ Subjects with BMI between 18 and $25 \mathrm{~kg} / \mathrm{m}^{2}$ were classified as having normal weight, while those with BMI $30 \mathrm{~kg} / \mathrm{m}^{2}$ and above were classified as being obese. ${ }^{9}$ Waist circumference (WC) was measured in centimeters $(\mathrm{cm})$ along the mid-point between the costal margin and the iliac crest along the mid-axillary line. ${ }^{19}$ The International Diabetes Federation (IDF)'s reference values for male and female were used. In males, WC of less than or equal to $94 \mathrm{~cm}$ was regarded as normal, while WC of greater than $94 \mathrm{~cm}$ was regarded as abnormal. In females, $\mathrm{WC}$ of less than or equal to $80 \mathrm{~cm}$ was regarded as normal while WC of greater than $80 \mathrm{~cm}$ was taken to be abnormal. ${ }^{22}$

Three consecutive pulse rates were obtained and the mean recorded. Blood pressure (BP) was taken on the right arm with a mercury sphygmomanometer. ${ }^{23}$ The systolic and diastolic pressures were obtained. The disappearance of the korotkoff's sound (phase V) was the criterion for the diastolic blood pressure, and the average of three consecutive BP readings was recorded. BP was measured in a sitting position after 5 mins rest. Normal BP was defined as a systolic BP of less than $130 \mathrm{mmHg}$, and/or diastolic $\mathrm{BP}$ of less than $80 \mathrm{mmhHg}$. Those who did not satisfy these criteria were considered to have a high BP, in accordance with the BP target set by the American Diabetes Association (ADA). ${ }^{19}$

All the participants had their blood glucose estimated using the Accu-chek Active glucometer. The patients with T2DM had their urine samples tested for presence of urinary protein (albumin) using Combi-3 urinary strips from Medi-Test, Germany. The presence of one + and above of urine albumin was taken to be positive for albuminuria.

Glycated hemoglobin ( $\mathrm{HbA1c}$ ) was estimated using the In-2-it HbAlc device from BIO-RAD Laboratories, Flintshire, UK. It involves the use of boronate affinity chromatography to separate the glycated fraction from the non-glycated fraction. ${ }^{24}$ It measures the HbAlc level which reflects the average blood glucose level over the previous two or three months.
Glycemic control was assessed with the values of the HbAlc. HbAlc value was used to categorize the DM patients into two groups: good glycemic control (HbAlc $<7 \%$ ) and poor glycemic control ( $\mathrm{HbA} 1 \mathrm{c} \geq 7 \%)^{25}$

\section{Criteria for the diagnosis of thyroid dysfunction}

Participants with raised TSH, and low fT3 and fT4 were regarded to have primary hypothyroidism; those who had elevated TSH, but with normal fT3 and fT4 were taken to have subclinical hypothyroidism. ${ }^{26-28}$ In the same vein, those who had low TSH, and high fT3 and fT4 were regarded to have primary hyperthyroidism; those who had low TSH but with normal fT3, and fT4 were taken to have subclinical hyperthyroidism. ${ }^{27-29}$ The subjects with low or normal TSH, but had low fT3 and fT4 were taken to have secondary hypothyroidism. ${ }^{28,30}$

\section{Procedure for thyroid function assay}

Frozen sera from the T2DM subjects and controls were thawed and allowed to attain room temperature. The samples were assayed for free $\mathrm{T} 3$, free $\mathrm{T} 4$ and $\mathrm{TSH}$, respectively, in batches, in three runs, each on a different day. Control samples provided in the reagents kits were analyzed with each run of the analytes following the manufacturer's instructions.

The data generated from the study were analyzed using the Statistical Package for the Social Sciences (SPSS) IBM version 17. A statistical comparison was made with the student $t$-test for quantitative variables like weight, height, blood pressure, serum TSH, serum T3; Chi-square test was used for comparison of proportions. Regression (linear) analysis was used to determine the relationship between the level of glycated hemoglobin and the presence of hypothyroidism or hyperthyroidism, while logistic regression analysis was used to determine the relationship between thyroid dysfunction and some variables like glycated haemoglobinduration of DM, complications of DM. A $p$-value of less than 0.05 was taken as being statistically significant.

\section{Results}

\section{Sociodemographic characteristics}

Females formed the majority of the study population accounting for $56.5 \%$ of the T2 DM patients and $62.7 \%$ of the controls. Most of the participants had either tertiary education $(38.3 \%)$ or secondary level of education $(22.7 \%)$. Majority of the participants $(65.3 \%)$ were 
married. Retirees (28.8\%) and Civil servants (26.3\%) formed the majority of the participants as shown in Table 1.

\section{Clinical characteristics of the participants}

The mean age of the T2DM patients in this study was 57.5 $( \pm 9.3)$ years, while the controls had a similar mean age of 57.7 \pm 8.9 ( $p=0.17$ ). The mean age at diagnosis of DM was $54 \pm 7.6$ years. The mean duration of DM for all the T2DM patients was $6.5 \pm 2.8$ years. Table 2 shows that T2DM patients had higher mean BMI than the controls $(27.6 \pm 5.0$ vs $26.2 \pm 3.8)$. This difference was statistically significant $(\mathrm{t}=-2.7 ; p=0.002)$. The T2DM patients also had higher mean waist circumference $(90.2 \pm 13.9$ vs $87.5 \pm 11.0)$, and this difference was also statistically significant $(\mathrm{t}=-2.2, p=0.03)$.

\section{Medication use among T2DM patients}

About $98 \%$ of T2DM patients were using only oral medications for DM (any of metformin, glibenclamide, glimepiride and vildagliptin); $32.7 \%$ of $\mathrm{T} 2 \mathrm{DM}$ patients used both insulin and oral medications; $54.9 \%$ patients with type 2 DM were taking lipid-lowering drugs.

\section{Complications of DM}

The T2DM patients in this study had the following chronic complications of DM: DM retinopathy (49.1\%), peripheral neuropathy (48.1\%), DM nephropathy (13.0\%), DM foot ulcer (19.8\%). Thyroid dysfunction had a statistically significant relationship with DM nephropathy in this study as shown in Table 3. The other chronic complications of DM did not have significant relationship with thyroid dysfunction in this study.

\section{Glycemic control and thyroid dysfunction}

Linear regression analysis showed that $\mathrm{HbA1c}$ had a positive linear relationship with thyroid dysfunction (hypothyroidism or hyperthyroidism) with regression coefficient of $1.89(p=0.001)$. The regression equation is as follows: $\mathrm{HbA} 1 \mathrm{c}=4.17+1.89$ (class of thyroid function).

The value of $\mathrm{R}^{2}$ (coefficient of determination) was given as 0.107 which indicated that class of thyroid dysfunction can predict the level of HbAlc by $10.7 \%$ (poor predictive value). $\mathrm{HbA1c}$ had a negative correlation with free T3 levels in T2DM patients with thyroid dysfunction, with a correlation coefficient of -0.6 , and it was statistically significant $(p=0.001)$.

Table I Sociodemographic characteristics of study participants

\begin{tabular}{|c|c|c|c|c|c|}
\hline & Total & T2DM & Control & $\mathrm{X}^{2}$ & $p$-value \\
\hline & $N=472, n(\%)$ & $N=354, n(\%)$ & $N=1 \mid 8, n(\%)$ & & \\
\hline Gender & & & & 1.40 & 0.28 \\
\hline Male & $198(4 \mid .9)$ & $154(43.5)$ & $44(37.3)$ & & \\
\hline Female & $274(58.1)$ & $200(56.5)$ & $74(62.7)$ & & \\
\hline Occupation & & & & 6.4 & 0.17 \\
\hline Traders & $93(19.7)$ & $78(22)$ & $15(12.7)$ & & \\
\hline Civil Servants & I33 (28.2) & $93(26.3)$ & $40(33.9)$ & & \\
\hline Private sectors & $102(21.6)$ & $76(21.5)$ & $26(22.0)$ & & \\
\hline Students & $8(1.7)$ & $5(1.4)$ & $3(2.5)$ & & \\
\hline Retirees/No employment & $136(28.8)$ & $102(28.8)$ & $34(28.8)$ & & \\
\hline Educational Status & & & & 0.42 & 0.94 \\
\hline None & $138(29.2)$ & $103(29.1)$ & $35(29.7)$ & & \\
\hline Primary Education & $46(9.7)$ & $33(9.3)$ & $13(11.0)$ & & \\
\hline Secondary Education & $107(22.7)$ & $82(23.2)$ & $25(2 \mid .2)$ & & \\
\hline Tertiary Education & 181 (38.3) & $136(38.4)$ & $45(38.1)$ & & \\
\hline Marital Status & & & & 0.3 & 0.85 \\
\hline Single & II (2.3) & $9(2.5)$ & $2(1.7)$ & & \\
\hline Married & $310(65.7)$ & $231(65.3)$ & 79 (66.9) & & \\
\hline Widowed & $151(32.0)$ & $114(32.2)$ & $37(31.4)$ & & \\
\hline Family History of DM & & & & 14.0 & $0.001 *$ \\
\hline Yes & $163(34.5)$ & $139(39.3)$ & $24(20.3)$ & & \\
\hline No & $309(65.5)$ & $215(60.7)$ & 94 (79.7) & & \\
\hline
\end{tabular}

Note: ${ }^{*} p$-value is statistically significant.

Abbreviations: DM, Diabetes mellitus; $X$, Chi square; T2DM, type 2 diabetes mellitus. 
Table 2 Clinical characteristics of study participants

\begin{tabular}{|c|c|c|c|c|}
\hline & T2DM patients & Control & \multirow[t]{2}{*}{$t$-value } & \multirow[t]{2}{*}{$p$-value } \\
\hline & $N=354($ Mean \pm SD $)$ & $N=1 \mid 8($ Mean $\pm S D)$ & & \\
\hline Mean age (years) & $57.5( \pm 9.3)$ & $57.7( \pm 8.9)$ & 0.17 & 0.17 \\
\hline $\mathrm{BMI}\left(\mathrm{kg} / \mathrm{m}^{2}\right)$ & $27.6( \pm 5.0)$ & $26.2( \pm 3.8)$ & -2.7 & $0.002^{*}$ \\
\hline Waist Circumference $(\mathrm{cm})$ & $90.2( \pm 13.9)$ & $87.5( \pm \mid 1.0)$ & -2.2 & $0.03 *$ \\
\hline Weight (kg) & $72.0( \pm \mid 4.2)$ & $69.1( \pm 12.0)$ & 2.10 & $0.04 *$ \\
\hline Height (m) & $1.62( \pm 0.7)$ & $1.62( \pm 0.8)$ & -0.46 & 0.65 \\
\hline Systolic BP (mmHg) & $130.4( \pm \mid 8.7)$ & $127.5( \pm \mid 8.1)$ & -1.4 & 0.15 \\
\hline Diastolic BP (mmHg) & $81.7( \pm 9.5)$ & $80.2( \pm 9.1)$ & -1.5 & 0.13 \\
\hline
\end{tabular}

Note: $* P$-value is statistically significant.

Abbreviations: D, Standard deviation; BMI, Body mass index; BP, blood pressure; T2DM, type 2 diabetes mellitus.

Table 3 The relationship between the presence of DM complications and thyroid dysfunction

\begin{tabular}{|c|c|c|c|c|}
\hline $\begin{array}{l}\text { DM compli- } \\
\text { cations }\end{array}$ & $\begin{array}{l}\text { Thyroid } \\
\text { Yes } \\
\text { N=44, n } \\
(\%)\end{array}$ & $\begin{array}{l}\text { Dysfunction } \\
\text { No } \\
\text { N-3 I0, n (\%) }\end{array}$ & $x^{3}$ & $p$-value \\
\hline $\begin{array}{l}\text { Retinopathy } \\
\text { Yes } \\
\text { No }\end{array}$ & $\begin{array}{l}18(40.9) \\
26(59.1)\end{array}$ & $\begin{array}{l}156(50.3) \\
\text { I54 (49.7) }\end{array}$ & 1.37 & 0.26 \\
\hline $\begin{array}{l}\text { Nephropathy } \\
\text { Yes } \\
\text { No }\end{array}$ & $\begin{array}{l}17(8.6) \\
27(6.4)\end{array}$ & $\begin{array}{l}29(9.4) \\
28 ।(90.6)\end{array}$ & 29.2 & $0.00 I^{*}$ \\
\hline $\begin{array}{l}\text { Peripheral } \\
\text { Neuropathy } \\
\text { Yes } \\
\text { No }\end{array}$ & $\begin{array}{l}20(45.5) \\
24(24.5)\end{array}$ & $\begin{array}{l}152(49.0) \\
158(51.0)\end{array}$ & 0.2 & 0.75 \\
\hline $\begin{array}{l}\text { DM foot Ulcer } \\
\text { Yes } \\
\text { No }\end{array}$ & $\begin{array}{l}6(13.6) \\
38(86.4)\end{array}$ & $\begin{array}{l}64(20.6) \\
246(79.4)\end{array}$ & 1.2 & 0.32 \\
\hline
\end{tabular}

Note: $* P$-value is statistically significant.

Abbreviation: DM, diabetes mellitus.

T2DM patients had significantly higher mean HbA1c $(7.8 \pm 20)$ than the controls $(5.8 \pm 1.2)$. This difference was statistically significant $(\mathrm{t}=10.3, p=0.001)$. Similarly, T2DM patients also had higher mean TSH $(4.4 \pm 1.5)$ than the controls $(4.2 \pm 2.0)$, although this difference was not statistically significant $(\mathrm{t}=-0.9, p=0.37)$. The T2DM patients in this study had a higher mean fT4 $(1.47 \pm 0.6)$ than the controls $(1.41 \pm 0.5)$. This difference however was not statistically significant $(\mathrm{t}=1.10, p=0.33)$. Mean $\mathrm{fT} 3$ was lower in T2DM patients $(2.31 \pm 1.5)$ than in the controls $(2.72$ $\pm 2.2)$. This difference was statistically significant $(t=2.26$, $p=0.025)$ as shown in Table 4.

The mean HbA1c of the T2DM patients in this study was higher (7.8 \pm 2.0$)$ than that of the controls (5.8 \pm 1.2$)$. This difference was statistically significant $(\mathrm{t}=10.3, p=0.001)$.

The mean HbA1c of T2DM patients with thyroid dysfunction was higher $(8.1 \pm 1.9)$ than that of their counter-


the difference was statistically significant $(\mathrm{t}=-8.2$, $p=0.001)$. This is shown in Figure 1 .

Most $(70.8 \%)$ of the male T2DM patients had poor glycemic control, while only $29.2 \%$ of the males had good glycemic control as shown above in Table 5. The majority $(64.0 \%)$ of the female T2DM patients in this study had good glycemic control. This difference was statistically significant $\left(\chi^{2}=47.3, p<0.001\right)$.

There was a significant association between the presence of thyroid dysfunction and female gender $\left(\chi^{2}=20.3 ; p=0.001\right)$, duration of $\mathrm{DM}>5$ years $\left(\chi^{2}=7.7, p=0.005\right)$, central obesity

Table 4 Laboratory parameters of the participants

\begin{tabular}{|l|l|l|l|l|}
\hline & T2DM (Mean \pm S.D) & Control (Mean \pm S.D) & t-values & -values \\
\hline HbAlc (\%) & $7.8( \pm 2.0)$ & $5.8( \pm 1.2)$ & 10.3 & $0.00 I^{*}$ \\
TSH $(\mathrm{mU})$ & $4.4( \pm 1.5)$ & $4.2( \pm 2.0)$ & -0.9 & 0.37 \\
fT4 $(\mathrm{ng} / \mathrm{dl})$ & $1.47( \pm 0.6)$ & $1.41( \pm 0.5)$ & 1.10 & 0.33 \\
fT3 $(\mathrm{pg} / \mathrm{ml})$ & $2.3( \pm 1.5)$ & $2.72( \pm 2.2)$ & 2.26 & $0.025^{*}$ \\
\hline
\end{tabular}

Note: $* P$-value is statistically significant.

Abbreviations: S.D, standard deviation; DM, diabetes mellitus; T2DM, type 2 diabetes mellitus; fT3, free 3,5,3-triiodothyronine; fT4, free 3,5,3',5'-tetraiodothyronine; $\mathrm{HbAlc}$, glycosylated hemoglobin; TSH, thyroid-stimulating hormone. 




Figure I Mean HbAlc of the study population.

Abbreviations: HbAlc, glycosylated hemoglobin; T2DM, type 2 diabetes mellitus.

Table 5 Categories of HbAlc

\begin{tabular}{|l|l|l|}
\hline \multirow{2}{*}{ HbAlc value } & Male & Female \\
\cline { 2 - 3 } & N=154, N (\%) & N=200, N (\%) \\
\hline Good control; HbAlc $<7 \%$ & $45(29.2)$ & I28 (64.0) \\
\hline Poor control; HbAlc $\geq 7 \%$ & $109(70.8)$ & $72(36.0)$ \\
\hline
\end{tabular}

Note: $X^{2}=47.3$,

Abbreviation: $\mathrm{HbAlc}$, glycosylated hemoglobin

$\left(\chi^{2}=24.8 ; p=0.001\right)$, nephropathy $\left(\chi^{2}=29.2, p=0.001\right)$ and $\mathrm{HbAlc} \geq 7 \%\left(\chi^{2}=5.0, p=0.04\right)$ as shown in Table 6 .

Binary logistic regression showed that female gender (OR=3.8, $p=0.002)$, central obesity ( $\mathrm{OR}=2.5, p=0.001), \mathrm{DM}$ duration $>5$ years $(\mathrm{OR}=3.3, p=0.012), \mathrm{HbA} 1 \mathrm{c} \geq 7 \quad(\mathrm{OR}=4.3$, $p=0.025)$ and $\mathrm{DM}$ nephropathy $(\mathrm{OR}=4.8, p=0.001)$ were risk factors for thyroid dysfunction (see Table 7).

\section{Discussion}

Females formed $58.1 \%$ of the participants. Females also constituted $56.5 \%$ of the T2DM patients. This female preponderance is similar to the $60.5 \%$ reported by the Diabcare Nigeria study group in 2012 in a multi-center study that assessed the profile of Nigerians with DM. ${ }^{31}$ It is also close to $57.9 \%$ reported by Okafor et al in Enugu, Nigeria, in 2012 in a study that evaluated the cardio-metabolic risk factors in Nigerians living with T2DM. ${ }^{32}$ However, it is in contrast to the pattern observed in studies involving diabetic patients outside the tertiary health institutions in Nigeria, where the ratio was close to $1: 1 .^{33}$ The male to female ratio in NHANES III study, a community-based study involving over 33,994 persons, was $1: 1{ }^{34}$ This might be a reflection of the pattern of health care financing in Enugu and other parts of Nigeria. Health care is largely financed by the individual, and as such, women are more likely to get financial assistance from relations and loved ones toward hospital care. ${ }^{31}$ It may also be due to a better health-seeking behavior exhibited by women as was reported by Omuemu et al in a community-based study conducted in Edo state, Nigeria, in 2007..$^{32}$ More so, women are more likely to visit health care facilities for other health-related activities like family planning clinics, where a hitherto unknown medical condition could be diagnosed for the first time. A population-based study will be able to establish the true sex distribution of persons with DM in the population.

The mean age of T2DM patients in this study was 57.5 years. This may be due to the fact that the prevalence of T2DM increases with age. ${ }^{20,25,35,36}$ This reflects the pattern observed by Chinenye et al (57.1) in a multi-center study involving DM patients. ${ }^{31}$ Ofoegbu et al reported a mean age of 59.2 years in Enugu in a study that evaluated the body composition of Nigerians with DM. ${ }^{35}$ Okafor et al in Enugu reported 55.7 years as the mean age of T2DM patients they evaluated for cardio-metabolic risk factors. ${ }^{32}$ This is lower than the figures reported from developed countries like New Zealand and the USA. ${ }^{37,38}$ This can be attributed to the lower life expectancy of Africans, and Nigerians in particular, compared to those of patients in the developed world. 
Table 6 Univariate analysis of the possible risk factors of thyroid dysfunction

\begin{tabular}{|c|c|c|c|c|}
\hline Variable & $\begin{array}{l}\text { Thyroid, } \\
\text { Yes } \\
\text { N=44, n } \\
(\%)\end{array}$ & $\begin{array}{l}\text { Dysfunction, } \\
\text { No } \\
\text { N=3 I 0, } \\
\text { n (\%) }\end{array}$ & $x^{3}$ & $p$-value \\
\hline \multicolumn{5}{|l|}{ Gender } \\
\hline Male & II (25) & $121(39.0)$ & 20.3 & $0.001 *$ \\
\hline Female & $33(75)$ & $189(61.0)$ & & \\
\hline Age (years) & & & 0.3 & 0.73 \\
\hline$\geq 60$ & $13(29.5)$ & $104(33.5)$ & & \\
\hline$<60$ & $31(70.5)$ & $206(66.5)$ & & \\
\hline $\begin{array}{l}\text { Duration of } \\
\text { DM (years) }\end{array}$ & & & 7.7 & $0.005^{*}$ \\
\hline$<5$ & $34(77.3)$ & |7| (55.2) & & \\
\hline$\geq 5$ & $10(22.7)$ & $139(44.8)$ & & \\
\hline HbAlc (\%) & & & 5.0 & $0.04 *$ \\
\hline$\geq 7$ & $27(61.4)$ & $135(43.5)$ & & \\
\hline$<7$ & $17(38.6)$ & $175(56.5)$ & & \\
\hline Hypertension & & & $0.65)$ & 0.43 \\
\hline Yes & $20(45.5)$ & 16I (5I.9) & & \\
\hline No & $24(54.5)$ & $149(48.1)$ & & \\
\hline $\begin{array}{l}\text { Central } \\
\text { obesity }\end{array}$ & & & 24.8 & $0.001 *$ \\
\hline Yes & $30(68.2)$ & $93(30.0)$ & & \\
\hline No & I4 (3I.8) & $217(70.0)$ & & \\
\hline Nephropathy & & & 29.2 & $0.001 *$ \\
\hline Yes & $17(8.6)$ & $29(9.4)$ & & \\
\hline No & $27(6.4)$ & $281(90.6)$ & & \\
\hline Retinopathy & & & 1.37 & 0.26 \\
\hline Yes & $18(40.9)$ & $156(50.3)$ & & \\
\hline No & $26(59.1)$ & 154 (49.7) & & \\
\hline $\begin{array}{l}\text { Peripheral } \\
\text { neuropathy }\end{array}$ & & & 0.2 & 0.75 \\
\hline Yes & $20(45.5)$ & $152(49.0)$ & & \\
\hline No & $24(54.5)$ & I58 (5I.0) & & \\
\hline DM foot ulcer & & & 1.2 & 0.32 \\
\hline Yes & $6(13.6)$ & $64(20.6)$ & & \\
\hline No & $38(86.4)$ & $246(79.4)$ & & \\
\hline
\end{tabular}

Note: $* P$-value is statistically significant.

Abbreviation: DM, diabetes mellitus.

The mean age at diagnosis of T2DM in this study was 54 years which is similar to that observed in the UKPDS (54 years), ${ }^{39}$ but is a bit higher than 48.3 years reported by the Diabcare Nigeria study group. ${ }^{31}$ The mean duration of DM of 6.5 years is similar to 6.7 years observed by Okafor et al in Enugu and reflects the pattern reported in other Nigerian studies, ${ }^{31,32}$ but is low when compared to that observed in the developed world. ${ }^{38}$ This might mean that most diabetics in Enugu and other parts of Nigeria do not survive long enough, which might be a pointer to the disease burden and quality of care available to the patients.

There was a significant difference $(p=0.001)$ in the mean duration of DM between those that have thyroid dysfunction (9.5 years) and those that are euthyroid (6.0 years). This might be an indication that increasing duration of DM may be a risk factor in the prevalence of thyroid dysfunction as chronic hyperglycemia impairs the peripheral deiodination of T4 to T3 leading to thyroid dysfunction.

The mean HbA1c of $7.8 \%$ observed in T2DM patients in this study is close to $8.3 \%$ reported by the Diabcare Nigeria study group. However, this contrasted with findings in a study assessing quality of care for diabetes in the USA. $^{40}$ T2DM patients in this study had significantly higher mean HbA1C $(\mathrm{t}=-8.2, p=0.001)$. This could be a reflection of poor glycemic status of most DM patients in our environment as fifty-one per cent (51\%) of the T2DM subjects in this study did not achieve glycemic goal, which reflects the pattern in earlier studies. ${ }^{16,17,31,32}$ Poor drug adherence may be a major contributing factor. Financial constraints are yet another important factor. Most patients have to pay out-of-pocket for their investigations and drugs. According to a WHO report, $74.5 \%$ of the health care cost in Nigeria is borne by the patients. ${ }^{41}$

T2DM patients in this study had lower mean T3 levels compared to the controls. Udenze et al found that patients with metabolic syndrome in Lagos, Nigeria, had lower mean T3 levels compared to their controls. ${ }^{42}$ This could be the effects of long-term hyperglycemia on the peripheral deiodination of T4 to T3, and/or the blunting of nocturnal peak in TRH secretion by chronic hyperglycemia in patients with T2DM. ${ }^{8,43}$ Poorly managed diabetes have been found to induce a "low T3 state" characterized by low serum total and free T3 levels. ${ }^{8,43}$

There was an inverse relationship between HbAlc and serum free $\mathrm{T} 3$, and a positive relationship between $\mathrm{HbA} 1 \mathrm{c}$ and TSH in the T2DM patients with hypothyroidism (who formed the majority) in this study. This relationship could be attributed to the effect of chronic hyperglycemia, seen in T2DM, on the peripheral deiodination of T4 to T3. This is similar to the report of Bazrafshan et al in Gorgan, Iran, ${ }^{44}$ who found a positive relationship between $\mathrm{HbAlc}$ and $\mathrm{TSH}$ in T2DM patients they studied. Similar results were reported by Asmabi et el who studied 100 patients with diabetes.

In this study, HbA1c had a positive linear relationship with the presence of hypothyroidism or hyperthyroidism (regression coefficient $=1.89, p=0.001)$. This suggests that poor 
Table 7 Multivariate analysis (logistic regression) of predictors/risk factors of thyroid dysfunction in type 2 DM patients

\begin{tabular}{|l|l|l|l|l|}
\hline Variables & OR & Cl (95\%) & Regression coefficient & p-value \\
\hline Female gender & 3.8 & $1.7-8.4$ & 1.32 & $0.002^{*}$ \\
Duration of DM (>5 years) & 3.3 & $1.5-7.9$ & -1.046 & $0.012^{*}$ \\
Hbalc ( $\geq 7 \%)$ & 4.3 & $2.1-8.9$ & 0.8 & $-0.025^{*}$ \\
DM nephropathy & 4.8 & $2.2-10.5$ & 1.57 & $0.00 I^{*}$ \\
Central obesity & 2.5 & $1.2-5.2$ & -1.378 & $0.00 I^{*}$ \\
\hline
\end{tabular}

Note: $* P$-value is statistically significant.

Abbreviations: DM, diabetes mellitus; HbAlc, glycosylated hemoglobin.

glycemic control (increased HbA1c) is directly linked to the development of thyroid dysfunction in T2DM. This may be as a result of the effect of hyperglycemia on hypothalamo-pituitary-thyroid axis that ultimately leads to low T3 levels in patients with DM. It may also be due to the hyperglycemiainduced inhibition of peripheral deiodination of T4 to T3, causing a low T3 state. ${ }^{8,43,45}$

\section{Limitations}

Assaying for thyroid hormones using the more sensitive chemilumniscent immunoassay method would have sought out more patients with thyroid dysfunction and inability to do fasting blood glucose in the control group and T2DM patients in this study.

\section{Conclusion}

HbAlc had a positive linear relationship with thyroid dysfunction.

\section{Ethics approval and consent to participate}

Ethical approval was obtained from the University of Nigeria Health Research Ethics Committee of the UNTH University of Nigeria Teaching Hospital Enugu before commencing the study. Written informed consent was obtained from all subjects participating in the study. This study was conducted in accordance with the Declaration of Helsinki. Consent for publication was not applicable.

\section{Data availability}

The data used to support the findings of this study are available from the corresponding author upon request.

\section{Abbreviations list}

T2DM, type 2 diabetes mellitus; T1DM, type 1 diabetes mellitus; DM: diabetes mellitus; fT3, free 3,5,3-triiodothyronine; fT4, free 3,5,3',5'-tetraiodothyronine; HbAlc, glycosylated hemoglobin; TSH, thyroid-stimulating hormone; BMI, Body Mass Index; SPSS, Statistical Package for the Social Sciences; IBM, International Business Machine; NHANES III, National Health and Nutritional Education Survey III; UNTH, University of Nigeria Teaching Hospital; RBG, random blood glucose; UKPDS, United Kingdom Prospective Diabetes Study; CLIA, Chemilumniscent immunoassay.

\section{Acknowledgments}

We thank staff of the Department of Medicine, University of Nigeria Teaching Hospital, Enugu, Nigeria, who contributed toward the article by making substantial contributions to the conception and revision of manuscript for important intellectual content. This research did not receive specific funding.

\section{Author contributions}

All authors contributed towards data analysis, drafting and critically revising the paper, gave final approval of the version to be published, and agreed to be responsible for all versions of the work.

\section{Disclosure}

The authors report no conflicts of interest in regard to this work.

\section{References}

1. O'Meara NM, Blackman JD, Sturis J, Polonsky KS. Alterations in the kinetics of c-peptide and insulin secretion in hyperthyroidism. J Clin Endocrinol Metab. 1993;76:79-84. doi:10.1210/jcem.76.6.8501157

2. Dimitriadis G, Baker B, Marsh H. Effect of thyroid hormone excess on action, secretion, and metabolism of insulin in humans. Am J Physiol. 1985;248:593-601.

3. Beer SF, Pair JH, Temple RC, Hales CN. The effect of thyroid disease on pro-insulin and c-peptide levels. Clin Endocrinol. 1989;30:379383. doi:10.1111/j.1365-2265.1989.tb00435.x

4. Levine RJ, Smyth DH. The effect of the thyroid gland on intestinal absorption of hexoses. J Physiol. 1963;169:755-769. doi:10.1113/ jphysiol.1963.sp007294

5. Matty AJ, Seshadri B. Effect of thyroxine on the isolated rat intestine. Gut. 1965;6:200-202. doi:10.1136/gut.6.2.200 
6. Kemp HF, Hundal HS, Taylor PM. Glucose transport correlates with GLUT 2 abundance in rat liver during altered thyroid status. Mol Cell Endocrinol. 1997;128:97-102. doi:10.1016/S0303-7207(97)04026-4

7. Mokuno T, Uchimura K, Hayashi R. Glucose transporter 2 concentrations in hyper and hypothyroid rat livers. $J$ Endocrinol. 1999;160:285-289. doi:10.1677/joe.0.1600285

8. Papazafiropoulou A, Sotiropoulos A, Kokolaki A, Lardara M, Stamataki P, Pappas S. Prevalence of thyroid dysfunction among Greek type 2 diabetic patients. J Clin Med Res. 2010;2:75-78. doi:10.4021/jocmr2010.03.281w

9. Feely J, Isles TE. Screening for thyroid dysfunction in diabetics. $\mathrm{Br}$ Med J. 1979;1:1678. doi:10.1136/bmj.1.6179.1678

10. Gray RS, Irvine WJ, Clarke BF. Screening for thyroid dysfunction in diabetics. Br Med J. 1979;2:1439. doi:10.1136/bmj.2.6202.1439-a

11. Perros P, McCrimmon RJ, Shaw G, Frier BM. Frequency of thyroid dysfunction in diabetic patients: value of annual screening. Diabet Med. 1995;12:622-627.

12. Cardoso C, Ohwovoriole AE, Kuku SF. A study of thyroid function and prevalence of thyroid auto-antibodies in an African diabetic population J Diabet Complicat. 1995;9:37-41. doi:10.1016/1056-8727(93)00022-3

13. Smithson MJ. Screening for thyroid dysfunction in a community of diabetic patients. Diabet Med. 1998;15:148-150. doi:10.1002/(SICI) 1096-9136(199802)15:2<148::AID-DIA540>3.0.CO;2-H

14. Celami MF, Bonati ME, Stucci N. Prevalence of abnormal thyrotropin concentrations measured by a sensitive assay in patients with type 2 diabetes mellitus. Diabetes Care. 1997;20:1183-1197.

15. Udiong CEJ, Udoh E, Etukudoh ME. Evaluation of thyroid function in diabetes mellitus in Calabar, Nigeria. Indian $J$ Clin Biochem. 2007;22:74-78. doi:10.1007/BF02913318

16. Pasupathi P, Bakthavathsalam G, Saravanan G. Sundaramoorthi R Screening for thyroid dysfunction in the diabetic/non-diabetic population. Thyroid Sci. 2008;3:1-6.

17. Ghazali SM, Abbiyesuku FM. Thyroid dysfunction in type 2 diabetics seen at the University College Hospital, Ibadan, Nigeria. Niger J Physiol Sci. 2010;25:173-179.

18. American Diabetes Association. Diagnosis and classification of diabetes mellitus. Diabetes Care. 2012;35:S11-S19. doi:10.2337/dc12-s011

19. Gale EAM, Anderson JV. Diabetes mellitus and other disorders of metabolism. In: Kumar P, Clark M, editors. Kumar and Clark's Clinical Medicine. London: Elsevier Ltd; 2012:1001-1046.

20. Akbar DH, Ahmed MM, Al-Mughales J. Thyroid dysfunction and thyroid autoimmunity in Saudi type 2 diabetics. Actadiabetologica. 2006;43:14-18.

21. World Health Organisation (WHO). Obesity: preventing and managing the global epidemic. Report of WHO consultation. WHO technical report series 894. Geneva: World Health Organisation; 2000. Accessed June 6, 2015.

22. Gezawa ID, Puepet FH, Mubi MB, Haliru I, Bakki B, Tella MA. Anthropometric correlates of insulin resistance: a study of healthy Nigerian adults. Kamen J Med Sci. 2010;4:14-18.

23. O'Gara PT, Loscalzo J. Physical examination of the cardiovascular system. In: DL L, AS F, DL K, SL H, JL J, Loscalzo J, editors. Harrison's Principles of Internal Medicine. Vol. 19. New York: McGraw- Hill Medical; 2014:1442-1456.

24. Turner HE, Wass TAH. Diabetes. In: Turner HE, Wass TAH, editors. Oxford Handbook of Endocrinology and Diabetes. New York: Oxford University Press; 2010:724-822.

25. Cooper DS, Greenspan FS, Ladenson PN. The thyroid gland. In: Gardner DG, Shoback D, editors. Greenspan's Basic and Clinical Endocrinology. New York: McGraw-Hill Medical; 2007:209-280.

26. Jameson JL, Mandel SJ, Weetman AP. Disorders of the thyroid gland. In: Longo DL, Fauci AS, Kasper DL, Hauser SL, Jameson JL, Localzo J, editors. Harrison's Principles of Internal Medicine. New York: McGraw-Hill Medical; 2014:2251-2334.
27. Turner HE, Wass TAH. Thyroid. In: Turner HE, Wass TAH, editors. Oxford Handbook of Endocrinology and Diabetes. New York: Oxford University press; 2010:2-70.

28. Jameson JL, Weetman AP. Disorders of thyroid gland. In: Longo DL, Fauci AS, Kasper DL, Hauser SL, Jameson JL, Localzo J, editors. Harrison's Principles of Internal Medicine. New York: McGraw-Hill Medical; 2012:2911-2939.

29. American Diabetes Association. Standards of medical care in diabetes. Diabetes Care. 2014;37:S14-S80. doi:10.2337/dc14S014

30. Chinenye S, Uloko AE, Ogbera AO, et al. Profile of Nigerians with diabetes mellitus. Diabcare Nigeria study group (2008). Results of a multi-centre study. Indian J Endocrinol Metab. 2012;16:558-564. doi:10.4103/2230-8210.98011

31. Okafor CI, Ofoegbu EN. Control to goal of cardiometabolic risk factors among Nigerians living with type 2 diabetes mellitus. Niger J Clin Pract. 2012;15:15-18. doi:10.4103/1119-3077.9 4089

32. Otimi CN, Chen G, Oli J, et al. Calpain-10 gene polymorphisms and type 2 diabetes in West Africans. The Africa America Diabetes Mellitus (AADM) study. Ann Epidemiol. 2005;15:153-159. doi:10.1016/j.annepidem.2004.05.014

33. Hollowell GJ, Staehling NW, Flaunders WD, et al. Serum TSH, T4 and thyroid antibodies in the United States population, (1988-1994): National Health and Nutrition Examination Survey (NHANES) III. $J$ Clin Endocrinol Metab. 2002;87:489-499. doi:10.1210/jcem.8 7.2.8182

34. Powers AC. Diabetes mellitus: diagnosis, classification, management and complications. In: Longo DL, Fauci AS, Kasper DL, Hauser SL, Jameson JL, Localzo J, editors. Harrison's Principles of Internal Medicine. 19th ed. New York: McGraw-Hill Medical; 2014:2399-2430.

35. Ofoegbu EN, Oli JM, Igwe JC. Body composition of Nigerian diabetics using Bioimpedance analysis (BIA). Niger Health Biomed Sci. 2004;3:37-39.

36. Chuang LM, Tsai ST, Huang BY, Tai TY, on behalf of Diabcare Asia 1998 Study Group. The status of diabetes control in Asia - a crosssectional survey of 24,317 patients with diabetes mellitus in 1998 . Diabet Med. 2002;19:978-985.

37. McMicheal AJ, Beaglehole R. The changing global concept of public health. Lancet. 2000;356:495-499.

38. United Kingdom Prospective Study Group, 1998. Intensive blood glucose control with sulphonylureas or insulin compared with conventional treatment and risk of complications in patients with type 2 diabetes mellitus. Lancet. 1998;352:837-853.

39. Jifeng M. Diabetes Care Quality Indicators. Tampa: The Medicare Quality Improvement Organisation for Florida; 2006.

40. WHO 2004 Diabetes Action Now Booklet. Geneva, Switzerland: World Health Organisation; 2004. Available from: https://www.who. int/diabetes/actionnow/booklet/en/. Accessed July 1, 2019.

41. Udenze I, Nnaji I, Oshodi T. Thyroid function in adult Nigerians with metabolic syndrome. Pan Afr Med J. 2014;18:352-354. doi:10.11604/pamj.2014.18.352.4551

42. Hage M, Zantout MS, Azar ST. Thyroid disorders and diabetes mellitus. J Thyr Res. 2011;31:39-45.

43. Bazrafsham HR, Ramezani A, Salehu A. Thyroid dysfunction and its relation with diabetes (NIDDM). J Gorgan Uni Med Sci. 2002;2:5-11.

44. Famuyiwa OO. Cardiac disease in Nigerians with thyrotoxicosis. Trop Cardiol. 1987;13:15-19.

45. Singh G, Gupta V, AK S, Gupta N. Evaluation of thyroid dysfunction among type 2 diabetic Punjabi population. Adv Biores. 2011;2:3-9. 


\section{Publish your work in this journal}

Diabetes, Metabolic Syndrome and Obesity: Targets and Therapy is an international, peer-reviewed open-access journal committed to the rapid publication of the latest laboratory and clinical findings in the fields of diabetes, metabolic syndrome and obesity research. Original research, review, case reports, hypothesis formation, expert opinion and commentaries are all considered for publication. The manuscript management system is completely online and includes a very quick and fair peer-review system, which is all easy to use. Visit http://www.dovepress.com/testimonials.php to read real quotes from published authors.

Submit your manuscript here: https://www.dovepress.com/diabetes-metabolic-syndrome-and-obesity-targets-and-therapy-journal 